UDK 343.121:343.131.5

343.126.1(4-67EU:497.5)

Review article

\title{
PROCEDURAL RIGHTS OF SUSPECTS AND ACCUSED PERSONS DURING PRE-TRIAL DETENTION - IMPACT OF DETENTION CONDITIONS ON EFFICIENT EXERCISE OF DEFENCE RIGHTS
}

\author{
Marija Pleić, PhD, Assistant Professor \\ University of Split, Faculty of Law \\ Domovinskog rata 8, 21000 Split, Croatia \\ marija.pleic@pravst.hr
}

\begin{abstract}
The paper analyses the possibilities of detainees to effectively exercise their defence rights during the pre-trial detention. Deprivation of liberty presupposes limited abilities of detainees to move and to take actions and, consequently, it may affect their possibilities to exercise the rights guaranteed by the law. Hence, a correlation between material conditions of detention and defence rights can be perceived. Inadequate detention conditions, in addition to leading to inhuman and degrading treatment, can also pose an obstacle for the full enjoyment of procedural rights, primarily the right of access to a lawyer, the right to have adequate time and facilities for the preparation of defence. In this regard, detention conditions can lead to the violation of the right to a fair trial. On the other hand, effective exercise of the right to access to a lawyer is one of the most important guarantees of protection against torture, inhuman and degrading treatment during detention. Therefore it is necessary not only to legally prescribe the special procedural guarantees for suspects and accused deprived of their liberty but also to provide such material conditions, which are often limited and insufficient within the prison systems, for the enforcement of the pre-trial detention in a way which will enable the full and efficient exercise of the defence rights guaranteed by the law.

In the paper, the author analyses the procedural guarantees for detainees which are enshrined within the EU directives on procedural rights of suspects and accused persons and the ECtHR case law in the light of detention conditions. Special attention in paper has been given to the Croatian law and an assessment of the procedural rights and detention conditions in pre-trial detention within the national legal framework and case law.
\end{abstract}

Keywords: pre-trial detention, detention conditions, procedural rights, right of access to a lawyer, inhuman and degrading treatment 


\section{INTRODUCTION}

The analysis of pre-trial detention as the coercive measure of deprivation of liberty in criminal proceedings entails two different aspects. ${ }^{1}$ On the one hand, the procedural aspect encompasses procedural requirements for ordering a pre-trial detention under criminal procedure law. On the other hand, the penitentiary aspect relates to detention conditions in pre-trial detention. Even though these two aspects differ in their content and regulatory framework, ${ }^{2}$ they are correlated and interdependent. The procedural requirements are the basis for the application of detention and therefore indispensable for avoiding excessive use of pre-trial detention and, consequently, overcrowding of prison system. ${ }^{3}$ However, inadequate detention conditions, in addition to leading to inhuman and degrading treatment, can pose an obstacle for the successful exercise of procedural rights, primarily the right of access to a lawyer or the right to have adequate time and facilities for the preparation of defence.

Deprivation of liberty and all further inherent restrictions may affect the ability to prepare a proper defence in the criminal proceedings. Such circumstances which do not exist on the part of the defendants at liberty may further increase the differences in the procedural position of the defendant deprived of liberty in relation to the public prosecutor in the criminal proceedings. Therefore, it is necessary to ensure not only additional procedural guarantees for the defendants deprived of liberty but also such objective conditions for the execution of the measure of deprivation of liberty that will enable the full exercise of defence rights guaranteed by the criminal procedure legislation.

In the course of time, the European Court for Human Rights (ECtHR) developed an extensive and abundant case law on pre-trial detention under Article 5 of the European Convention for the Protection of Human Rights and Fundamental Freedoms (ECHR) and on procedural rights of defendants under the right to a fair trial (Article 6). Yet, in the last decade the European Union has been intensifying its legislative activity regarding the procedural rights of defendants in the criminal procedure. In the framework of the Roadmap for strengthening procedural

1 In the context of this paper, pre-trial detention relates to the procedural measure of deprivation of liberty determined by a court before or during the criminal proceedings, i.e., it includes all detainees not serving the final sentence. The analysis does not include the police arrest or police detention

2 Detention conditions and prisoners' rights are mainly regulated by the penitentiary soft law documents: European Prison Rules, UN Mandela Rules

3 Van Kempen, P. H., Pre-trial detention in national and international law and practice: a comparative synthesis and analyses, in: Van Kempen, P. H. (ed), Pre-Trial Detention: Human Rights, Criminal Procedural Law and Penitentiary Law, Comparative Law, Cambridge - Antwerp - Portland, Intersentia, 2012, p. 38 
rights of suspects and accused in criminal proceedings, six directives on procedural rights have been adopted so far. One of the issues covered in the Roadmap (measure F), that has not been subject to the EU directive yet, is pre-trial detention. ${ }^{4}$ Despite the identified problems in the practice of EU Member States in relation to pre-trial detention, there is currently no consensus among the Member States on such EU legislative activity in the field of detention that would result in the harmonisation of detention rules. ${ }^{5}$ The analysis of Member State responses to the European Commission Green Paper on Detention ${ }^{6}$ indicates that excessive use of pre-trial detention is not caused to such an extent by legislative shortcomings as it is caused by the inappropriate implementation of existing national legislation in practice. Hence, some authors indicate that additional common standards on pretrial detention are unlikely to substantially improve the criminal procedural rules of EU Member States. ${ }^{7}$ However, there are calls for further action at the EU level to strengthen the rights of suspected or accused persons in criminal proceedings aimed, inter alia, at taking measures regarding pre-trial detention. ${ }^{8}$

Additionally, ECtHR case law and research indicate that detention conditions in EU Member States still fail to comply with the established international standards and that the excessive number of pre-trial detainees is still one of the main factors leading to prison overcrowding in some EU Member States. ${ }^{9}$ According to the Council of Europe Annual Penal Statistic, 22\% of inmates held in the European prisons on 31 st January 2019 were not serving a final sentence. ${ }^{10}$ The Republic of

4 Van Ballegooij, W., Procedural Rights and Detention Conditions, Cost of Non - Europe Report, European Parliamentary Research Service, Bruxelles, 2017, p. 63, available at: [https://www.europarl.europa.eu/ RegData/etudes/STUD/2017/611008/EPRS_STU(2017)611008_EN.pdf], accessed 24. June 2020

5 For details on EU activity in the field of pre-trial detention see Pleić, M., Pritvor u pravu Europske unije, Zbornik radova s međunarodnog znanstvenog savjetovanja "Europeizacija kaznenog prava i zaštita ljudskih prava u kaznenom postupku i postupku izvršenja kaznenopravnih sankcija”, Split, 2017, pp $269-273$

6 European Commission, Strengthening mutual trust in the European judicial area - A Green Paper on the application of EU criminal justice legislation in the field of detention, COM (2011) 327 final, Brussels, 14.6.2011

7 Coventry, T., Pretrial detention: Assessing European Union Competence under Article 82(2) TFEU, New Journal of European Criminal Law, vol. 8, no. 1, 2017, p. 61

8 Hence, the European Criminal Bar Association (ECBA) proposes adoption of a new Roadmap on minimum standards of certain procedural safeguards Riehle, C.; Clozel, A., 10 years after the roadmap: procedural rights in criminal proceedings in the EU today, ERA Forum 20,321-325, 2020, [https://doi. org/10.1007/s12027-019-00579-5], accessed 24. June 2020

$9 \quad$ Van Ballegooij, op. cit. note 4, p. 7, 10

10 Aebi, M. F.; Tiago, M. M., SPACE I - 2019 - Council of Europe Annual Penal Statistics: Prison populations, Strasbourg: Council of Europe, 2020, p. 48, The percentage of detainees not serving a final sentence varies broadly across countries, ranging from $2.8 \%$ to roughly $48 \%$ in countries with at least one million inhabitants, and reaching $83 \%$ in smaller countries. Aebi, M. F.; Tiago, M. M., Pris- 
Croatia is at the 13 th place with $31 \%$. Although the median prison density for European countries was below 100 (89.5\%, and $80.0 \%$ for Croatia) on 31 January 2019, prison density rates for several EU Member States (Belgium, Italy, Hungary, France, Denmark, Czech Republic, Austria, Slovenia) indicate overcrowding. ${ }^{11}$ Nevertheless, there is currently no EU legislation providing harmonised standards on detention conditions. ${ }^{12}$

In the past decade, ECtHR has delivered several pilot judgements identifying structural deficiencies of the national prison systems, however the recent case law indicates that these problems still affect certain EU Member States. ${ }^{13}$ In fact, in the most recent judgement issued in 2020, J.M.B. (no. 9671/15) and Others v. France, the Court concluded that the occupancy rates of the prisons in question disclosed a structural problem. ${ }^{14}$ Similarly, in 2019 in Petrescu v. Portugal, the Court recommended that the Portuguese State envisage the adoption of measures which will ensure that prisoners were provided with conditions of detention compatible with Article 3 as well as remedy to be made available to prevent the continuation of an alleged violation or to enable prisoners to secure an improvement in their conditions of detention. ${ }^{15}$

Although detention conditions, i.e. the prison regime, primarily belong within the competence and responsibility of the Member States, this issue affects the EU to the extent that inadequate detention conditions which fall under the scope of Art. 4 of Charter of Fundamental Rights of the European Union (CFREU) and Art. 3 of ECHR can undermine the principle of mutual trust and effective judicial cooperation between the Member States. ${ }^{16}$ Hence, the Court of Justice of the European Union (CJEU) confirmed in its ruling Aranyosi/Căldăraru that mutual

ons and Prisoners in Europe 2019: Key Findings of the SPACE I report, p. 6, [http://wp.unil.ch/space/ files/2020/04/Key-Findings-2019_200406.pdf], accessed 24. June 2020

11 SPACE I - 2019, op. cit. note 10, p. 72

12 Conditions of detention are mentioned in the Directive on procedural safeguards for children who are suspects or accused persons in criminal proceedings. Van Ballegooij, op. cit, note 4, p. 64

13 See Ananyev and others v. Russia, app. no. 42525/07 60800/08, 10.1.2012, Torreggiani and others v. Italy, app. no.43517/09, 8.1.2013, Vasilescu v. Belgium, app. no. 64682/12, 25.11.2014, Neshkov and Others v. Bulgaria, app. no. 36925/10, 27.1.2015, Varga and Others v. Hungary, app. no. 14097/12, 10.3.2015, Rezmives and Others v. Romania, app. no. 61467/12, 25.4.2017

14 Court found violation of Article 13 in respect of 32 applicants and a violation of Article 3 in respect of 27 applicants. J.M.B. (no. 9671/15) and Others v. France, SS 221, 302, app. no. 9671/15, 20.1.2020

15 Similar conclusion regarding violation of Article 13 was reached in relation to 25 applicants in Koureas and Others v. Greece, $\$ 911$, app. no. 30030/15, 18.1.2018

16 See Pleić, M., Challenges in cross-border transfer of prisoners: EU framework and Croatian perspective, in: Duić, D.; Petrašević, T. (eds), EU and Comparative Law Issues and Challenges, Osijek: Josip Juraj Strossmayer University of Osijek, Faculty of Law Osijek, 2018, p. 386 - 388 
trust does not imply blind trust, ${ }^{17}$ and set an obligation for the executing Member States to assess detention conditions in the issuing Member States before executing the European Arrest Warrant. ${ }^{18}$ In its recent case law (ML and Dorobantu cases), following the Aranyosi/Căldăraru case, the CJEU further elaborated on how to conduct an individual assessment of whether there is a real risk of inhuman and degrading treatment. ${ }^{19}$

The following chapters present the analysis of the procedural guarantees for detainees which are enshrined within the EU law and the ECHR case law in the light of detention conditions within which these rights have been exercised. The analysis is followed by the assessment of procedural rights and detention conditions in pre-trial detention within the national (Croatian) law.

\section{DEFENCE RIGHTS OF PRE-TRIAL DETAINEES IN THE LIGHT OF DETENTION CONDITIONS IN EUROPEAN LAW}

\subsection{Procedural guarantees for suspects and accused persons deprived of liberty under the EU law}

Even though the pre-trial detention procedure is not regulated by EU legislation, the procedural rights directives, deriving from the premise that deprivation of liberty requires the accused to be granted stronger guarantees than in the regular cases, ${ }^{20}$ prescribed additional requirements to the Member States in relation to suspects and accused persons deprived of liberty in criminal proceedings. Hence, the first measure adopted under the Roadmap, Directive 2010/64/EU on the right to interpretation and translation, considers the decision depriving a person of his liberty to be the essential document requiring written translation if the suspects or accused persons do not understand the language of the criminal proceedings. ${ }^{21}$

${ }_{17} \quad$ van der Mei, A. P., The European Arrest Warrant system: Recent developments in the case law of the Court of Justice, Maastricht Journal of European and Comparative Law 2017, vol. 24, no. 6, p. 899, [http:// journals.sagepub.com/doi/pdf/10.1177/1023263X17745804], a accessed 24. June 2020

18 Joined Cases C404/15 and C659/15 PPU, Pál Aranyosi and Robert Căldăraru, [2016] EU:C:2016:198

19 Case C-22/18 PPU, ML [2018] ECLI:EU:C:2018:589, Case C-128/18, Dorobantu, [2019] ECLI:EU:C:2019:857, see European Union Agency for Fundamental Rights, Criminal detention conditions in the European Union: rules and reality, Luxembourg, 2019, p. 11, available at: [https:// fra.europa.eu/en/publication/2019/criminal-detention-conditions-european-union-rules-and-reality], accessed 15. July 2020

20 Quattrocolo, S., The Right to Information in EU Legislation, in: Ruggeri, S. (ed.), Human Rights in European Criminal Law, New Developments in European Legislation and Case Law after the Lisbon Treaty, Springer International Publishing Switzerland 2015, p. 86

21 Directive 2010/64/EU of the European Parliament and of the Council of 20 October 2010 on the right to interpretation and translation in criminal proceedings, OJ L 280, 26.10.2010, p. 1-7 
This right is a prerequisite for challenging the lawfulness of detention of a defendant who does not understand the language of proceedings.

The provision of information to the suspects and accused persons regarding their rights and the charges brought against them represents the precondition for an efficient defence. The research has shown that the defendants deprived of liberty are placed in an inherently more stressful situation and the impact of this is apparent in both their understanding of their rights and their ability to exercise them. ${ }^{22}$ Considering the peculiar situation of arrested and detained persons, ${ }^{23}$ the Directive on the right to information in criminal proceedings ${ }^{24}$ requires more extensive information to be provided to suspects or accused persons deprived of liberty in relation to the ones at liberty. In that sense, the Directive went beyond the requirements of ECHR and ECtHR as it requires a written letter of rights to be delivered to the defendants deprived of liberty. ${ }^{25}$ In addition, according to Article 6 of the Directive, arrested or detained persons must be promptly informed about the reasons for the arrest or detention, which corresponds to the procedural safeguard guaranteed in article $5 \$ 2$ ECHR. ${ }^{26}$ The third aspect of the right to information relates to the right of access to the materials of the case. This right also implies an additional guarantee for the suspects and accused deprived of liberty. In that sense, the Directive requires that the documents which are essential to effectively challenging the lawfulness of the arrest or detention be made available to the arrested persons or their lawyers. ${ }^{27}$

Since the right of access to a lawyer is at the core of defence rights, the Directive on the right of access to a lawyer adopted under a considerable influence of the ECtHR case law (Salduz) strengthened the existing guarantees and set a higher level of obligations for the situations in which the suspect or accused person is deprived

22 European Union Agency for Fundamental Rights, Rights in practice: access to a lawyer and procedural rights in criminal and European arrest warrant proceedings, Luxembourg: Publications Office of the European Union, 2019, p. 42, available at: [https://fra.europa.eu/en/publication/2019/rights-practice-access-lawyer-and-procedural-rights-criminal-and-european-arrest], accessed 15. July 2020

23 Quattrocolo, op. cit. note 20, p. 86

24 Directive 2012/13/EU of the European Parliament and of the Council of 22 May 2012 on the right to information in criminal proceedings, OJ L 142, 1.6.2012, p. 1-10

25 See Cras, S.; De Matteis, L., The Directive on the rights to information, Eucrim 1/2013, p. 26, 27

26 Allegrezza, S.; Covolo, V., The Directive 2012/13/EU on the right to information in criminal proceedings: Status Quo Or Step Forward?, in: Đurđević, Z.; Ivičević Karas, E. (eds), European Criminal Procedure law in service of protection if the Union financial interests: State of Play and Challenges, Zagreb, 2016, p. 46

$27 \quad$ Art 7 Directive 
of liberty. ${ }^{28}$ It guarantees access to a lawyer without undue delay after the deprivation of liberty. Furthermore, confidentiality of communication is guaranteed in absolute terms. Humanitarian aspect, as one of the purposes of the right to legal assistance highlighted by Trechsel, is especially important in relation to the defendant deprived of liberty whose feelings of desperation are particularly strong. ${ }^{29}$

Even though the Directive on the right of access to a lawyer, as well as other directives, aims primarily to safeguard the defence rights of the defendant in criminal proceedings, there is a noticeable link between the procedural rights guaranteed by the Directive and the detention conditions in which these rights should be exercised. In that sense, in the Recital the Directive refers to the conditions in which the suspects or accused persons are deprived of liberty and calls for full respect of the established European standards. Furthermore, it is emphasised that the lawyer providing assistance under this Directive should be able to raise a question with the competent authorities regarding the conditions in which that person is deprived of liberty, ${ }^{30}$ which is in line with the ECtHR case law.

Besides the pivotal right of access to a lawyer which is guaranteed to all suspects and accused persons irrespective of whether they are deprived of liberty, the Directive guarantees the rights directed specifically towards the persons deprived of liberty, namely the right to have a third person informed of the deprivation of liberty, the right to communicate with third persons while deprived of liberty and the right to communicate with consular authorities. These rights in a special way aim at strengthening the protection of the persons deprived of liberty against potential abuses during detention. The Directive does not precise the manner (means, frequency, duration, conditions) in which the latter rights will be exercised as these issues affect the penitentiary regime and go beyond the scope of the Directive. ${ }^{31}$ It is left to a Member States to make practical arrangements for the exercise of these rights taking account of the need to maintain good order, safety and security in the place where the person is being deprived of liberty. However, considering that inadequate detention conditions may undermine the exercise of the right to

28 Directive 2013/48/EU of the European Parliament and of the Council of 22 October 2013 on the right of access to a lawyer in criminal proceedings and in European arrest warrant proceedings, and on the right to have a third party informed upon deprivation of liberty and to communicate with third persons and with consular authorities while deprived of liberty, OJ L 294, 6.11.2013, p. 1-12, Recital 28, see Cras, S., The Directive on the Right of Access to a Lawyer in Criminal Proceedings and in European Arrest Warrant Proceedings, Eucrim 1/2014, p. 36

29 Trechsel, S., Human Rights in Criminal Proceedings, Oxford, 2005, p. 246

30 Recital 22 of Directive

31 Bachmaier Winter, L., The EU Directive on the Right to Access to a Lawyer: A Critical Assessment, in: Ruggeri, S. (ed.), Human Rights in European Criminal Law, New Developments in European Legislation and Case Law after the Lisbon Treaty, Springer International Publishing Switzerland 2015, p. 126 
communicate with a third person, it would have been appropriate to highlight the need that the exercise of this right is not subject to unjustified conditions by the Member States. ${ }^{32}$

The last measure on procedural rights adopted under the Roadmap, the Directive on the right to legal aid, ${ }^{33}$ aims to ensure the effectiveness of the right of access to a lawyer by making available the assistance of a lawyer funded by the Member States $^{34}$ to persons who lack sufficient resources to pay for the assistance of a lawyer when the interests of justice so require. ${ }^{35}$ The deprivation of liberty is one such situation where the interests of justice require legal aid, ${ }^{36}$ and in that sense, the Directive prescribes the merits test, which the Member States may apply in determining whether legal aid is to be granted, should been deemed to have been met where a suspect or an accused person is brought before a competent court or judge in order to decide on detention at any stage of the proceedings and during detention. ${ }^{37}$

Finally, in the context of procedural rights of the suspects and accused deprived of their liberty, it is important to address the presumption of innocence as the backbone of the defendant's legal position in the criminal proceedings. Although the presumption of innocence should apply equally to defendants regardless of whether they are deprived of their liberty or not, the fact of deprivation of liberty and the inherent restriction of other rights can additionally call this guarantee into question. In that sense, the Directive on the presumption of innocence sets higher requirements, especially in relation to public references to guilt and presentation of suspects and accused persons. ${ }^{38}$ The latter is of particular significance in relation to pre-trial detainees and the manner in which they are brought and held in court. Hence, the Directive requires from the competent authorities to abstain from presenting the suspects or accused persons as guilty, in court or in public, through the use of measures of physical restraint, such as handcuffs, glass boxes, cages and

\section{$32 \quad$ Ibidem}

33 Directive (EU) 2016/1919 of the European Parliament and of the Council of 26 October 2016 on legal aid for suspects and accused persons in criminal proceedings and for requested persons in European arrest warrant proceedings, OJ L 297, 4.11.2016, p. 1-8

34 Recital 1 of Directive

35 Article 4 of Directive

36 Cras, S., The Directive on the Right to Legal Aid in Criminal and EAW Proceedings, Genesis and Description of the Sixth Instrument of the 2009 Roadmap, Eucrim 1/2017, p. 40

37 Article 4

38 Directive (EU) 2016/343 of the European Parliament and of the Council of 9 March 2016 on the strengthening of certain aspects of the presumption of innocence and of the right to be present at the trial in criminal proceedings, OJ L 65, 11.3.2016, p. 1-11 
leg irons, unless the use of such measures is required for case-specific reasons. ${ }^{39}$ This practice of placing a defendant in a glass cage during the hearing has occasionally been examined in the context of the guarantee of the presumption of innocence under Article 6 (2) of the Convention but later the Court began to examine the practice also from the standpoint of Article 3 of the Convention as inhuman and degrading treatment. ${ }^{40}$

\subsection{Impact of detention conditions on efficient exercise of defence rights of pre- trial detainees-}

\subsubsection{Right to have adequate facilities for preparation of defence}

One of the minimum defence rights guaranteed by Article 6(3)(b) ECHR is the right to have adequate time and facilities for the preparation of defence. This right overlaps with the right to legal assistance stated in Art 6(3)(c) and they are both particularly significant to the persons in pre-trial detention, ${ }^{41}$ as confirmed by the ECtHR case law.

The Court reiterated in its practice that the States' duty under Article $6 \$ 3$ (b) includes an obligation to "organise the proceedings in such a way as not to prejudice the accused's power to concentrate and apply mental dexterity in defending his position". ${ }^{42}$ When a person is detained pending trial, exercise of this right depends not only on the procedural norms and criminal procedure authorities but also on the detention conditions and prison authorities. In that sense, ECtHR explained that "the notion of facilities may include such conditions of detention that permit the person to read and write with a reasonable degree of concentration". 43 The conditions of detention transport, catering and other similar arrangements are relevant factors to consider in this respect. ${ }^{44}$

The right to adequate facilities presupposes the access to the case file, and the deprivation of liberty raises the question of the possibility for detainees to access

\footnotetext{
39 Art. 5 Directive, Recital 20 of Directive

40 Khodorkovskiy v. Russia, $\$ 123$, app. no. 5829/04, 31.5.2011

41 Harris, D.J. et al., Harris, O'Boyle \& Warbrick, Law of the European Convention on Human Rights, Oxford University Press, 2014, p. 472

42 See Makhfi v. France, $\$ \$ 40-41$, app. no. 59335/00, 19.10.2004

43 Moiseyev v. Russia, app. no. 62936/00, 9.10.2008, \$221, see Guide on Article 6 of the European Convention on Human Rights, Right to a fair trial (criminal limb), Council of Europe/European Court of Human Rights, 2020, p. 72, available at: [https://www.echr.coe.int/Documents/Guide_Art_6_criminal_ENG.pdf], accessed 18. Jul 2020

44 Guide on Article 6 of the European Convention on Human Rights, Right to a fair trial (criminal limb), 72
} 
the case file in a way that will enable the actual benefit of that right under their limited possibilities for movement and exercise of other fundamental rights. Even if guaranteed by the law, this right may be limited in terms of the time in which the defendant can access the file, the possibility of copying certain parts of the file. These problems were emphasised in Dolenec v. Croatia where the Court found a violation of Art 6(1) taken together with Art. 6(3)..$^{45}$ The Court noted that during the entire trial, save for two days, the applicant was in detention and thus not in a position to freely consult his case file. He had the opportunity to examine the case file, which was quite voluminous, and copy certain documents only once during the trial. He made several requests to consult the case file, but all of his requests remained unanswered. ${ }^{46}$

In Moiseyev, the Court concluded that the applicant's trial was unfair because the prosecuting authority had unrestricted discretion in the matter of visits by counsel and exchanges of documents, access by the applicant and his defence team to the case file and their own notes was severely limited, and the applicant did not enjoy adequate conditions for the preparation of his defence. ${ }^{47}$ These inadequate conditions relate to the transport between the remand centre and the courthouse for more than one hundred and fifty times in prison vans, which were sometimes filled beyond their designated capacity, without adequate ventilation and lighting, and with unreliable heating. Furthermore, having regard to the cumulative effect which these conditions of transport had on the applicant, the Court found that they amounted to inhuman treatment within the meaning of Article 3. Hence, the same circumstance led to the violation of prohibition of inhuman and degrading treatment and of the right to a fair trial. The Court reiterated here its assessment provided in Khudoyorov v. Russia, where it examined for the first time the compatibility of transport conditions between the detention facility and the courthouse with the requirements of Article $3,{ }^{48}$ that the applicant was subjected to such treatment during his trial or at the hearings regarding the applications for an extension of his detention, i.e., when he most needed his powers of concentration and mental alertness. ${ }^{49}$ However, in Razvozzhayev v. Russia and Ukraine and Udaltsov v. Russia, even though the intensity of the court hearing schedule did not reach a sufficient level of severity to qualify as inhuman or degrading treatment within the meaning of Article 3, the Court concluded that it affected the first applicant's ability to effectively participate in the proceedings and to instruct his lawyers con-

Dolenec v. Croatia, app. no. 25282/06, 26.11.2009., \$218

Ibidem, $\$ \$ 209-218$

Moiseyev v. Russia, app. no. 62936/00, 9.10.2008, \$ 224.

48 Khudoyorov v. Russia, app. no. 6847/02, 8.11.2005, $\$ 118-120$

49 Moiseyev v. Russia, $\$ 135$, Khudoyorov v. Russia, $\$ 120$ 
trary to the requirements of Article 6(1) and (3) (b). The cumulative effect of exhaustion caused by lengthy prison transfers leaving less than eight hours of rest, repeated for four days a week over a period of more than four months, seriously undermined the first applicant's ability to follow the proceedings, file submissions, take notes and instruct his lawyers and therefore he had not been afforded adequate facilities for the preparation of his defence. ${ }^{50}$

\subsubsection{Right of access to a lawyer}

The importance of the right of access to a lawyer as a fundamental safeguard against ill-treatment of pre-trial detainees was repeatedly emphasised in the recommendations of the European Committee for the Prevention of Torture and Inhuman or Degrading Treatment or Punishment, and the Court confirmed it in Salduz v Turkey. ${ }^{51}$ In the concurring opinion on Salduz, it was pointed out that the fact that the defence counsel may see the accused throughout his detention in police stations or in prison is more apt than any other measure to prevent treatment prohibited by Article 3 of the Convention. ${ }^{52}$ The Court has acknowledged this on numerous occasions since the Salduz and recently in Beuze v Belgium, where it emphasised that account must be taken, on a case-by-case basis in assessing the overall fairness of the proceedings, of the whole range of services specifically associated with legal assistance: discussion of the case, organisation of the defence, collection of exculpatory evidence, preparation for questioning, support for an accused in distress, and finally verification of the conditions of detention. ${ }^{53}$

As ECtHR repeated on several occasions, assigning counsel to represent a party at the proceedings does not in itself ensure the effectiveness of the assistance. ${ }^{54}$ The issues in the relationship and communication between the defendant and the lawyer may especially arise in cases where the defendant is deprived of liberty when the possibility of contact and the development of trust are relatively limited. Thus, in Moiseyev the Court noted that the counsel was required to seek special permits to visit and confer with the applicant. Permits, which were issued by the authority in charge of the case, were valid for one visit only and the lawyers' attempts to have their period of validity extended proved to be unsuccessful. Hence, for the entire duration of the criminal proceedings against the applicant, the visits by the

\footnotetext{
50 Razvozzhayev v.Russia and Ukraine and Udaltsov v. Russia, app. no. 75734/12 and others, 19.11.2019, $\$ \$ 254-255$

$51 \quad$ Salduz v Turkey, app. no. 36391/02, 27.11.2008, \$54

52 Salduz v Turkey, Concurring opinion of Judge Zagrebelsky, joined by Judges Casadevall and Türme

$53 \quad$ Salduz v Turkey, $\$ 136$

54 Maderv Croatia, app. no. 56185/07, 21.6.2011, $\$ 161$
} 
applicant's counsel were conditional on authorisation by the authorities. ${ }^{55}$ In the light of the above, the Court found that the control exercised by the prosecution over access to the applicant by his counsel undermined the appearances of a fair trial and the principle of equality of arms. ${ }^{56}$ Furthermore, in Öcalan v. Turkey, the Court considered that the restriction of the number of visits and the length of the applicant's meetings with his lawyers was one of the factors that hindered the preparation of his defence. The applicant was allowed only two one-hour visits a week from his lawyer which was insufficient, given the complex charges and a voluminous case file. ${ }^{57}$ Yet, in Mader $v$ Croatia the Court concluded that the lack of contact between the applicant and his officially appointed defence counsel, who had visited the applicant only once while in pre-trial detention, did not prejudice the applicant's defence rights to a degree incompatible with the requirements of a fair trial since the appointed defence counsel attended all hearings before the trial and actively participated by making relevant proposals and examining the witnesses. $^{58}$

In Dolenec, the applicant was represented by various officially appointed defence lawyers throughout the proceedings, save for two days, but it appears that there was a problem with communication as the applicant complained to the presiding judge that he had not been able to contact his counsel. The applicant further requested permission for a visit from his counsel in prison, but there was no answer to this request and there was no evidence that the counsel actually visited the applicant at all. It is important to reiterate the Court's view that the relevant prison authorities should keep a record of the appointed counsel's visits to the applicant in prison in order to make sure that the defence rights of the accused were respected. ${ }^{59}$ This view confirms and highlights the importance of the active role of the prison administration in setting the preconditions for the exercise of guaranteed rights of defence.

The precondition for efficient exercise of defence rights, primarily the right of access to a lawyer, is the confidentiality of communication between the defendant and the lawyer. The issue of confidentiality and uninterrupted communication between the defendant and his/her lawyer is not disputable when the defendant is at liberty, but the problems may arise when the defendant is deprived of liberty and his/her possibilities of communication and contact with the outside world are

\footnotetext{
55 Moiseyev v. Russia, $\$ 204$

56 Ibidem, $\$ 207$

57 Öcalan v. Turkey, app. no. 46221/99,12.5.2005, \$ $134-135$

$58 \quad$ Mader v Croatia, $\$ 164,168-169$

59 Dolenec $v$ Croatia, \$ 212.
} 
limited and under the control of state authorities. ${ }^{60}$ ECtHR found a violation of Art 6(3)(c) when the accused, who was in pre-trial detention, was not allowed to consult with his layer out of hearing of a prison officer. ${ }^{61}$ It is important to emphasise the Court's conclusion that a measure of confinement in the courtroom, which we have already mentioned in relation to the presumption of innocence and inhuman and degrading treatment, may also have an impact on the exercise of the accused person's rights to effectively participate in the proceedings and to receive practical and effective legal assistance. In Khodorkovskiy and Lebedev v. Russia (No. 2), the applicants were separated from the rest of the hearing room by glass, a physical barrier which made it impossible for them to have confidential exchanges with their legal counsel, as they were physically removed from them, and any conversations between the applicants and their lawyers would be overheard by the guards in the courtroom. ${ }^{62}$

The right of confidential communication with the lawyer does not only apply to oral communication or face-to-face meetings but also to other forms of communication, such as telephone and written correspondence. ${ }^{63}$ The issues concerning prison correspondence have generally been considered under Article 8 ECHR within the right to respect for correspondence, even though the Court has also assessed this issue under Article 6 in the case when a delay in proceedings was caused by monitoring the defendant's correspondence with the lawyer. ${ }^{64}$

\section{PROCEDURAL RIGHTS AND DETENTION CONDITIONS OF PRE-TRIAL DETAINEES IN CROATIAN LAW}

\subsection{Procedural rights of pre-trial detainees}

In the Croatian criminal procedure law, the pre-trial detention, as the most severe measure for securing the presence of a defendant, is based on the constitutional principle of proportionality and, in accordance with the constitutional requirements, ${ }^{65}$ regulated in detail by the Criminal Procedure Act (the CPA). ${ }^{66}$ The

\footnotetext{
$60 \quad$ See Trechsel, op. cit., note 29, p. 278

${ }_{61} S$ v. Switzerland, app. no. 12629/87; 13965/88, 28.11.1991, $\$ 48-51$. See Harris, et al., op. cit., note 41, p. 482

62 Khodorkovskiy and Lebedev v. Russia (No. 2), app. nos. 51111//07 and 42757/07, 14.11.2020, \$648

63 See Trechsel, op. cit. note 29, p. 280

64 Domenchini v Italy, 101/1995/607/695, 15.11.1996, $\$ 39$, see Harris, et al., op. cit. note 41, p. 472

65 Article 22 of Constitution of Republic of Croatia, Official Gazette 56/90, 135/97, 113/00, 28/01, $76 / 10$ i $5 / 14$

66 Criminal Procedure Act, Official Gazette 152/08, 76/09, 80/11, 121/11, 91/12, 143/12, 56/13, 145/13, 152/14, 70/17, 126/19, 126/19. For details see Đurđević, Z.; Tripalo, D., Trajanje pritvora u
} 
CPA prescribes the grounds for pre-trial detention, duration of pre-trial detention which depends on the severity of the crime, jurisdiction (it can only be ordered by a judicial authority), procedure for ordering and vacating pre-trial detention, periodical ex officio control of its soundness and the optional control upon the appeal of the parties. ${ }^{67}$ Despite the fact that the Croatian legislation has set an appropriate procedure for pre-trial detention, ECtHR has found a violation of Article 5 ECHR in several judgements regarding the implementation of legislation in practice. The identified violations refer to the excessive length of pre-trial detention and the lack of sufficient justification for the extension of detention (Art 5(3)). ${ }^{68}$ In several judgements, including the recent Oravec v. Croatia, the Court has found that the Constitutional Court's practice of declaring constitutional complaints inadmissible where a fresh decision extending detention has been adopted before it has given its ruling is contrary to Article $5 \$ 4 .{ }^{69}$ Following the ECtHR findings, the Constitutional Court has decided to re-examine its practice. ${ }^{70}$

As regards the procedural position of pre-trial detainee during the criminal proceedings, the Croatian legislation has set the rules of procedure that seek to neutralise the unfavourable position of a defendant deprived of liberty in relation to a defendant at liberty, which is reflected in the limited possibilities of movement and consequent restriction of other fundamental rights. ${ }^{71}$ Therefore, the CPA requires special urgency of proceedings when the defendant has been deprived of liberty. ${ }^{72}$ The legislation concretises this requirement by prescribing shorter deadlines for undertaking certain procedural actions and for initiating and conducting certain stages of the procedure.

svjetlu medunarodnih standarda te domaćeg prava i prakse, Hrvatski ljetopis za kazneno pravo i praksu (Zagreb), vol. 13, no. 2, 2006, p. 568 et seq.

67 Article 122 - $134 \mathrm{CPA}$

${ }_{68}$ Dragin v. Croatia, app. no. 75068/12, 24.6.2014, \$ $120-121$; Margaretić v. Croatia, app. no. 16115/13, 5.6 2014; Perica Oreb v. Croatia, app. no. 20824/09, 31.10.2013, \$121 -122; Peśa v. Croatia, app. no. 40523/08, 8.4.2010, \$91; Dervishi v Croatia, app. no. 67341/10, 25.11.2012, \$144145; Trifković v. Croatia, app. no. 36653/09, 6.11.2012

${ }_{6}$ Oravec v. Croatia, no. 51249/11, 11.7.2017, $\$ 74$. Before this, the Court made the same conclusion in Peša v. Croatia, $\$ 126$, Hadi v. Croatia, app. no. 42998/08, 1.7.2010, $\$ 47$; Bernobić v. Croatia, app. no. 57180/09, 21.6.2011, $\$$ 93; Krnjak v. Croatia, app. no. 11228/10, , 28.6.2011 $\$$ 54; Šebalj v. Croatia, app. no. 4429/09, 28.6 2011, $\$ 223$; Getoš-Magdić v. Croatia, app. no. 56305/08, 2.12.2010, $\$ 106$; Trifković v. Croatia, $\$ \$ 139-140$,; Margaretić v. Croatia, $\$ \$ 119-21$

70 For details see Graovac, G., Nadležnost Ustavnog suda Republike Hrvatske ratione materiae glede istražnozatvorskih ustavnih tužbi, Hrvatski ljetopis za kaznene znanosti i praksu (Zagreb), vol. 24, no. 1, 2017, p. 125 et seq.

71 For more details see Pleić, M., Standardi izvršenja pritvora u kaznenom postupku, doctoral dissertation, Zagreb, 2014, p. 222

72 Article 11(2), Article 122 (3) CPA 
In accordance with the Directive on the right to interpretation and translation, the CPA guarantees the right of written translation of pre-trial detention ruling to the defendant who does not speak or understand the language of proceedings. Furthermore, the amendments to the CPA made in $2013^{73}$, which transposed the Directive on the right to information into the Croatian national law, introduced the written letter of rights for the arrestee and the obligation of delivery of the written letter of rights to the defendant together with the ruling on pre-trial detention. ${ }^{74}$

As mentioned above, the right of access to the file as part of the right to information is one of such rights the exercise of which may be hindered by the fact of deprivation of liberty, which may call into question the principle of equality of arms and the exercise of the right to adequate time and facilities to prepare a defence. ${ }^{75}$ The Croatian legislation provided, in accordance with the Directive on the right to information, for a substantive restriction on the possibility of denial of the right of access to the file so that all the evidence listed in the decision on the pre-trial detention, as the basis for ordering pre-trial detention, must be made available to the pre-trial detainee. ${ }^{76}$

The Croatian legislation has recognised the potential obstacles entailed by the deprivation of liberty in relation to the position of the defendant in the criminal proceedings and his/her ability to effectively prepare defence. Considering the fact that the right of access to a lawyer stands at the core of the right to defence, ${ }^{77}$ the Croatian legislation prescribes mandatory defence from the first moment of deprivation of liberty, i.e. from the issuance of the decision on the defendant's provisional confinement or pre-trail detention. ${ }^{78}$ In addition, in criminal proceedings for offences punishable by imprisonment of more than five years, the suspect who is subject to pre-trial detention proposal is entitled to a provisional legal aid at the expense of the state budgetary funds before the pre-trial detention hearing. ${ }^{79}$ However, the legislation should not have limited this right only to criminal proceedings for more severe criminal offences because it thus limits the scope of the

73 Act on Amendments to the CPA, Official Gazette 145/2013. For details on transposition of this Directive see Ivičević Karas, E.; Burić, Z.; Bonačić, M., Unapredenje procesnih prava osumnjičenika i okrivljenika u kaznenom postupku: pogled kroz prizmu europskih pravnih standarda, Hrvatski ljetopis za kaznene znanosti i praksu (Zagreb), vol. 23, no. 1, 2016, p. 36 - 39

74 Art 239 (a) CPA, Art 4 Directive on right to information

75 Pleić, op. cit. note 71, p. 252

76 Art 184a (4) CPA

77 Jimeno-Bulnes, M., The Right of Access to a Lawyer in the European Union: Directive 2013/48/ EU and Its Implementation in Spain, in: Rafaraci, T.; Belfiore, R. (eds.), EU Criminal Justice, Springer Nature Switzerland AG 2019, p. 58

78 Article 66 (1)(3) CPA

79 Art 72a (2) CPA 
Directive on the right to legal aid and makes it difficult for the defendants to efficiently contest the prosecutor's proposal for pre-trial detention.

In accordance with the Directive on the right of access to a lawyer which sets higher standards in relation to the right to confidential communication than the ECtHR case law, the amendments to the CPA made in 2017 deleted the provisions on the restriction of this right to the extent that it is now guaranteed as an absolute right. In addition to the general provision on free and confidential communication between the defendant and his/her lawyer (Art 64), the CPA emphasises said right in relation to the pre-trial detainee ${ }^{80}$ Furthermore, the Ordinance on house rules in prisons for the execution of pre-trial detention prescribes that a detainee has the right of free, undisturbed and unsupervised communication with the defence counsel, in a room designated for that purpose. ${ }^{81}$ The authorised official supervises the visit visually and without the possibility of listening. The authorised official may interrupt the visit if the prisoner or defence counsel violates the order and security in the prison or the usual orderly behaviour. Telephone communication and correspondence with the defence counsel shall be performed in a manner that guarantees the confidentiality of correspondence or telephone calls. ${ }^{82}$

The deprivation of liberty also raises the issue of the possibility of participation or presence of the defendant at the hearing and sessions of the panel during the trial. In that sense, the CPA prescribes the possibility of a defendant to participate in certain procedural activities (hearing for ordering, extending or vacating pre-trial detention, evidentiary hearing, session of the second instance panel). In relation to that, the amendments to the CPA made in 2013 deleted the part of the provision of Art. 475 stating that the presence of the pre-trial detainee at the second instance panel meeting depended on the assessment of the president of the court regarding the purposefulness of his presence, ${ }^{83}$ as this provision put the accused deprived of liberty in an unequal position in relation to the other party to the proceedings. The Constitutional Court of Republic of Croatia found a violation of the right to fair trial when the applicant's chosen defence counsel was prevented from participating at the session of the appellate panel and the applicant was not transported from detention, so his legal interests were protected only by the ex officio defence counsel whose representation power had been previously revoked by the applicant due to a disagreement over the defence strategy. ${ }^{84}$

\footnotetext{
80 See Pavlović, Š., Zakon o kaznenom postupku, Rijeka, 2017, p. 139 -140

81 Ordinance on house rules in prisons for the execution of pre-trial detention, Official Gazette 8/10

82 Article 18 of the Ordinance

83 Official Gazette 145/2013

84 Decision of Constitutional Court of Republic of Croatia, U-III-64667/2009, Zagreb, 1.3.2011
} 


\subsection{Detention conditions in pre-trial detention}

Although the Criminal Procedure Act, in the chapter Execution of pre-trial detention and treatment of pre-trial detainees (Art 135-143), and the Ordinance on house rules in prisons for the execution of pre-trial detention nominally comply with the standards set by the international instruments on the protection of the rights of persons deprived of liberty, these standards have not been implemented adequately in practice.

ECtHR and the Constitutional Court of Republic of Croatia on several occasions found a violation of Article 3 regarding the prison conditions in the Republic of Croatia, and some of these decisions relate to pre-trial detainees. One of these cases is Longin v. Croatia where the Court concluded that the detention conditions of the applicant confined in an overcrowded cell for twenty-two hours a day amounted to a degrading treatment incompatible with the requirements of Article 3 ECHR. ${ }^{85}$ Furthermore, the Constitutional Court, when examining the violation of Art. 23 and 25 of the Constitution and Art 3 ECHR, specifically emphasised that the applicant was a pre-trial detainee, hence his constitutional rights to personal liberty in terms of the presumption of innocence must be less restricted than that of a convicted prisoner. However, the national legislation granted more rights to convicted prisoners than to pre-trial detainees during the execution of pre-trial detention. ${ }^{86}$

In addition to the problems with implementation due to overcrowding, there were also some legislative deficiencies in the system of legal remedies for the pre-trial detainees regarding their complaints on detention conditions which precluded detainees from effective judicial protection of their rights. A major step towards the protection of detainees' rights during the execution of pre-trial detention and towards establishing jurisdiction for deciding constitutional complaints of pretrial detainees was made in 2008 by the decision of the Constitutional Court of Republic of Croatia which equated the legal remedies for the protection of detainees' rights with those guaranteed for prisoners. ${ }^{87}$ Thus the Constitutional

85 There were at least five beds to each cell, together with a dining table and chairs which did not leave much space for moving around. Furthermore, the sanitary facilities in the detention cells were not fully separated from the living area where the detainees were accommodated. Longin v. Croatia, app. no.49268/10, 6.11.2020, $\$ 60-62$. For details on judgements against Croatia see Ivičević Karas, E:, Ljudska prava i temeljne slobode u hrvatskom penitencijarnom pravu, in: Krapac, D. (ed.), Profili hrvatskog kaznenog zakonodavstva, Zagreb, 2014, p. 186 - 194

86 Constitutional Court of Republic of Croatia, U-III-4182/2008, 23.4.2008

87 Considering the fact that the CPA deficiently regulates the protection of detainees rights during the execution of pre-trial detention, while at the same time the Croatian penitentiary law adequately protects the rights of (convicted) prisoners, which are listed in the exhaustive catalogue contained in 
Court overcame a jurisdictional barrier, i.e. lack of their competence in this field, and established a legal basis for the constitutional review of violations of detainees' rights during the execution of pre-trial detention. ${ }^{88}$

However, the legislation and the case law were not harmonised for some years afterwards, and the problem of overcrowded prison system was still present. ${ }^{89}$ Such circumstances and the failure of the Government to fulfil positive obligations in order to establish adequate detention conditions in the prison system compelled the Constitutional Court to issue a Report on the detention conditions in the Republic of Croatia listing three categories of measures, in accordance with the $\mathrm{Eu}-$ ropean standards, which should have been implemented for the resolution of the detected problems. ${ }^{90}$ Finally, the recent amendments to the CPA made in 2017 introduced an effective legal remedy for the complaints of the pre-trial detainees, ${ }^{91}$ and in the meantime, the overcrowding has been somewhat decreased. ${ }^{92}$

The recent statistics show the worrisome trend of increase in the number of pretrial detainees. In the five-year period (from 2014 to 2018), the share of pre-trial detainees in the total prison population increased by as much as $10 \%$, while a more considerable increase is particularly discernible in 2017 and 2018. In fact, in 2014, the share of pre-trial detainees in the total prison population was almost

Article 14 para. 1 of the Execution of Prison Sentence Act, the Constitutional Court found that courts, applying the powers of an enforcement judge in relation to the request for the protection of prisoners' rights, are obliged to apply those same powers in relation to the complaints of detainees regarding the violations of their rights during detention. U-III-4182/2008, $\$ 20$

88 Krapac, D., Pretpostavke za pokretanje i vodenje ustavnosudskog postupka zaštite individualnih ustavnih prava $i$ sloboda: Pravni okvir i stvarne granice ("procesnost") hrvatskog modela ustavne tužbe, Hrvatsko ustavno sudovanje de lege lata i de lege ferenda, Okrugli stol održan 2. travnja 2009. U palači HAZU u Zagrebu, HAZU, Zagreb, 2009, p. 180. For more details on the constitutional protection of pre-trial detainees see Pleić, op.cit., note 73, pp. 322 - 332

89 In 2016, the Constitutional Court found a violation of Art 23 and 25 of the Constitution and Art 3 ECHR in relation to inadequate detention conditions in Lepoglava Prison where the applicants had not been provided with adequate personal space in their cells in accordance with the national law in the periods of six and nineteen months. Constitutional Court of Republic of Croatia, U-IIIBi-890/2012, 4.5.2016; Constitutional Court of Republic of Croatia, U-IIIBi-2475/2016 Zagreb, 5.10.2016, $\$ 10$

90 Constitutional Court of Republic of Croatia, U-X-5464/2012, 12.6.2014

91 According the Article 141(3) CPA, the investigating judge or the presiding judge or the single judge before whom the proceedings is conducted, who received the detainee's complaint shall examine the allegations in the complaint and the findings, as well as the measures taken to eliminate the observed irregularities, will notify the applicant in writing within thirty days of receiving the complaint

92 However, recently ECtHR found violations of Art 3 due to a lack of personal space in detention, though these judgements relate to situations in prison system from earlier period $(2010,2011)$ In Mursic v $v$. Croatia, the Court recapitulated its practice related to the personal space of persons deprived of their liberty in cells with several prisoners. Muršic v Croatia, app. no. 7334/13, 201.0.2016, $\$ 172$. See also_Ulemek $v$ Croatia, app. no. 21613/16, 31.10.2019, \$129-131 
$30 \%$, and in 2018 it increased to almost $40 \%$. In addition, the absolute number of pre-trial detainees increased significantly. ${ }^{93}$ It is evident that the declining trend in the number and share of pre-trial detainees in the total prison population, which began in 2008 (with the exception of 2013, when a sharp increase was recorded), has changed. A worrisome tendency to increase the number of pre-trial detainees has been detected in the recent years, especially if we take into account that the number of accused and convicted persons has been declining significantly in the same period. In 2008 there were over 30 thousand accused persons and in 2017 slightly less than 15 thousand,,${ }^{94}$ which means that in a ten-year period the number of accused and convicted persons has halved, while the number of pre-trial detainees does not follow such a trend.

\section{CONCLUSION}

For the efficient exercise of defence rights of a person deprived of liberty, it is primarily indispensable to set up a strict procedure of ordering a pre-trial detention with certain guarantees which will prevent abuse and excessive use of pre-trial detention. However, even if the legislation has set the appropriate legal framework for the protection of defence rights and the defendant has been granted the right of access to a lawyer, a number of factors related to detention conditions may adversely affect the full exercise of these rights and simultaneously lead to the violation of the right to a fair trial and inhuman and degrading treatment, as evident from the ECtHR case law.

A deficient legislation and the improper application of pre-trial detention create a vicious circle where excessive use of pre-trial detention leads to the overcrowding of the prison system. Consequently, the violation of the fundamental rights of detainees and inadequate prison conditions hinder the procedural position of defendants in criminal proceedings and disable efficient exercise of their procedural rights.

In order to prevent this, all measures, including normative and state authority measures, should take into account the interrelation between both aspects of pre-trial detention: procedural and penitentiary. Criminal procedure authorities

93 On 31.12.2015 there were 729 pre-trial detainees in the prison system, and on 31.12.2018 nearly a thousand pre-trial detainees (998). Izvješće o stanju i radu kaznionica, zatvora i odgojnih zavoda za 2018. Godinu, Vlada Republike Hrvatske, Zagreb, 2020., p. 21, [https:/www.sabor.hr/sites/default/ files/uploads/sabor/2020-01-03/162702/IZVJESCE_KAZNIONICE_2018.pdf], accessed 18. July 2020

94 Statistički ljetopis Republike Hrvatske 2018., Državni zavod za statistiku Republike Hrvatske, Zagreb, 2018, p. 572, [https://www.dzs.hr/], accessed 15. July 2020 
should take more account of these circumstances from the perspective of the defendant deprived of liberty in order to prevent and avert their unequal and inferior position in criminal proceedings. However, it is important to reiterate ECtHR's stance on the importance of the active role of prison administration in setting the preconditions for the exercise of guaranteed rights of defence.

Legal assistance in the cases of deprivation of liberty is not only desirable but also mandatory in the Croatian legislation due to aggravated possibilities of exercising the right to defence. In that aspect, the Croatian legislation goes beyond the requirements of the European standards. Even though the Croatian legislation has set an appropriate legal framework for pre-trial detention, there is a worrisome trend of increase in the number of pre-trial detainees which raises an issue of improper application of the pre-trial detention procedure and furthermore creates a risk of overcrowding the prison system.

In view of the above, the pre-trial detention procedure and detention conditions indeed affect and concern the EU functioning since the excessive use of pre-trial detention and inadequate detention condition infringe the fundamental rights of the suspects and accused persons and hamper mutual recognition. Considering the situation in the EU Member States, it would be advisable to strengthen the procedural rights of detainees with the EU common standards on pre-trial detention and detention conditions even though these problems arise more from the improper implementation and less from a deficient legislation. This issue has been present and reopened for some time now, and following the firm tendency to harmonise the criminal procedure law in the EU, the tackling of this issue seems logical and beneficial, especially in the context of smooth functioning of mutual recognition instruments required for setting the standards of pre-trial detention.

\section{REFERENCES}

\section{BOOKS AND ARTICLES}

1. Allegrezza, S.; Covolo, V., The Directive 2012/13/EU on the right to information in criminal proceedings: Status Quo Or Step Forward?, in Đurđević, Z.; Ivičević Karas, E. (eds), European Criminal Procedure law in service of protection if the Union financial interests: State of Play and Challenges, Zagreb, 2016, pp. $41-51$

2. Bachmaier Winter, L., The EU Directive on the Right to Access to a Lawyer: A Critical Assessment, in: Ruggeri, S. (ed), Human Rights in European Criminal Law, New Developments in European Legislation and Case Law after the Lisbon Treaty, Springer International Publishing Switzerland 2015, pp. $111-130$

3. Coventry, T., Pretrial detention: Assessing European Union Competence under Article 82(2) TFEU, New Journal of European Criminal Law, vol. 8, no. 1, 2017, pp. 43 - 60 
4. Cras, S., The Directive on the Right of Access to a Lawyer in Criminal Proceedings and in European Arrest Warrant Proceedings, Eucrim 1/2014, pp. 32 - 44

5. Cras, S., The Directive on the Right to Legal Aid in Criminal and EAW Proceedings, Genesis and Description of the Sixth Instrument of the 2009 Roadmap, Eucrim 1/2017, pp. $34-45$

6. Cras, S.; De Matteis, L., The Directive on the rights to information, Eucrim 1/2013, pp. 22 $-32$

7. Đurđević, Z.; Tripalo, D., Trajanje pritvora u svjetlu mectunarodnih standarda te domaćeg prava i prakse, Hrvatski ljetopis za kazneno pravo i praksu (Zagreb), vol. 13, no. 2, 2006, pp. $551-596$

8. Graovac, G., Nadležnost Ustavnog suda Republike Hrvatske ratione materiae glede istražnozatvorskih ustavnih tužbi, Hrvatski ljetopis za kaznene znanosti i praksu (Zagreb), vol. 24, no. 1, 2017, pp. $117-140$

9. Harris, D.J. et al., Harris, O'Boyle \& Warbrick, Law of the European Convention on Human Rights, Oxford University Press, 2014

10. Ivičević Karas, E.; Burić, Z.; Bonačić, M., Unapredenje procesnih prava osumnjičenika i okrivljenika u kaznenom postupku: pogled kroz prizmu europskih pravnih standarda, Hrvatski ljetopis za kaznene znanosti i praksu (Zagreb), vol. 23, no. 1, 2016, pp. 11 - 58

11. Ivičević Karas, E:, Ljudska prava i temeljne slobode u hrvatskom penitencijarnom pravu, in: Krapac, D. (ed.), Profili hrvatskog kaznenog zakonodavstva, Zagreb, 2014, pp. 175 - 205

12. Jimeno-Bulnes, M., The Right of Access to a Lawyer in the European Union: Directive 2013/48/ EU and Its Implementation in Spain, in: Rafaraci, T.; Belfiore, R. (eds.), EU Criminal Justice, Springer Nature Switzerland AG 2019, pp. 57 - 70

13. Krapac, D., Pretpostavke za pokretanje i vodenje ustavnosudskog postupka zaštite individualnih ustavnih prava i sloboda: Pravni okvir i stvarne granice ("procesnost") hrvatskog modela ustavne tužbe, Hrvatsko ustavno sudovanje de lege lata i de lege ferenda, Okrugli stol održan 2. travnja 2009. U palači HAZU u Zagrebu, HAZU, Zagreb, 2009, pp. 169 - 207

14. Pavlović, Š., Zakon o kaznenom postupku, Rijeka, 2017

15. Pleić, M., Challenges in cross-border transfer of prisoners: EU framework and Croatian perspective, in: Duić, D.; Petrašević, T. (eds), EU and Comparative Law Issues and Challenges, Osijek: Josip Juraj Strossmayer University of Osijek, Faculty of Law Osijek, 2018, pp. 375 $-399$

16. Pleić, M., Pritvor u pravu Europske unije, Zbornik radova s međunarodnog znanstvenog savjetovanja "Europeizacija kaznenog prava i zaštita ljudskih prava u kaznenom postupku i postupku izvršenja kaznenopravnih sankcija”, Split, 2017, pp. 265 - 290

17. Pleić, M., Standardi izvršsenja pritvora u kaznenom postupku, doctoral dissertaion, Zagreb, 2014

18. Quattrocolo, S.: The Right to Information in EU Legislation, in: Ruggeri, S. (ed.), Human Rights in European Criminal Law, New Developments in European Legislation and Case Law after the Lisbon Treaty, Springer International Publishing Switzerland 2015, pp. 81 92

19. Riehle, C.; Clozel, A., 10 years after the roadmap: procedural rights in criminal proceedings in the EU today, ERA Forum 20, 2020, p. 321-325 
20. Trechsel, S., Human Rights in Criminal Proceedings, Oxford, 2005

21. Van der Mei, A. P., The European Arrest Warrant system: Recent developments in the case law of the Court of Justice, Maastricht Journal of European and Comparative Law 2017, vol. 24, no. 6, pp. $882-904$

22. Van Kempen, P. H., Pre-trial detention in national and international law and practice: a comparative synthesis and analyses, in: Van Kempen, P. H. (ed.), Pre-Trial Detention: Human Rights, Criminal Procedural Law and Penitentiary Law, Comparative Law, Cambridge Antwerp - Portland, Intersentia, 2012, pp. 3 - 46

\section{EU LAW}

1. Case C-128/18, Dorobantu, [2019] ECLI:EU:C:2019:857

2. Case C-22/18 PPU, $M L$ [2018] ECLI:EU:C:2018:589

3. Directive (EU) 2016/1919 of the European Parliament and of the Council of 26 October 2016 on legal aid for suspects and accused persons in criminal proceedings and for requested persons in European arrest warrant proceedings, OJ L 297, 4.11.2016, p. 1-8

4. Directive (EU) 2016/343 of the European Parliament and of the Council of 9 March 2016 on the strengthening of certain aspects of the presumption of innocence and of the right to be present at the trial in criminal proceedings, OJ L 65, 11.3.2016, p. 1-11

5. Directive 2010/64/EU of the European Parliament and of the Council of 20 October 2010 on the right to interpretation and translation in criminal proceedings, OJ L 280, 26.10.2010, p. $1-7$

6. Directive 2012/13/EU of the European Parliament and of the Council of 22 May 2012 on the right to information in criminal proceedings, OJ L 142, 1.6.2012, p. 1-10

7. Directive 2013/48/EU of the European Parliament and of the Council of 22 October 2013 on the right of access to a lawyer in criminal proceedings and in European arrest warrant proceedings, and on the right to have a third party informed upon deprivation of liberty and to communicate with third persons and with consular authorities while deprived of liberty, OJ L 294, 6.11.2013, p. 1-12

8. Directive 2013/48/EU of the European Parliament and of the Council of 22 October 2013 on the right of access to a lawyer in criminal proceedings and in European arrest warrant proceedings, and on the right to have a third party informed upon deprivation of liberty and to communicate with third persons and with consular authorities while deprived of liberty, OJ L 294, 6.11.2013, p. 1-12

9. European Commission, Strengthening mutual trust in the European judicial area - A Green Paper on the application of EU criminal justice legislation in the field of detention, COM (2011) 327 final, Brussels, 14.6.2011.

10. Joined Cases C404/15 and C659/15 PPU, Pál Aranyosi and Robert Căldăraru, [2016] EU:C:2016:198 


\section{ECHR CASE LAW}

1. Ananyev and others $v$. Russia, app. no. 42525/07 60800/08, 10.1.2012

2. Torreggiani and others v. Italy, app. no.43517/09, 8.1.2013

3. Vasilescu v. Belgium, app. no. 64682/12, 25.11.2014

4. Neshkov and Others v. Bulgaria, app. no. 36925/10, 27.1.2015

5. Varga and Others v. Hungary, app. no. 14097/12, 10.3.2015

6. Rezmiveș and Others $v$. Romania, app. no. 61467/12, 25.4.2017

7. J.M.B. (no. 9671/15) and Others v. France, app. no. 9671/15, 20.1.2020

8. Koureas and Others v. Greece, app. no. 30030/15, 18.1.2018

9. Khodorkovskiy v. Russia, app. no. 5829/04, 31.5.2011

10. Makhfiv. France, app. no. 59335/00, 19.10.2004

11. Moiseyev v. Russia, app. no. 62936/00, 9.10.2008,

12. Dolenec v. Croatia, app. no. 25282/06, 26.11.2009

13. Khudoyorov v. Russia, app. no. 6847/02, 8.11.2005

14. Razvozzhayev v.Russia and Ukraine and Udaltsov v. Russia, app. no. 75734/12 and others, 19.11.2019

15. Salduz v Turkey, app. no. 36391/02, 27.11.2008,

16. Mader v Croatia, app. no. 56185/07, 21.6.2011,

17. Öcalan v. Turkey, app. no. 46221/99,12.5.2005

18. S v. Switzerland, app. no. 12629/87; 13965/88, 28.11.1991

19. Khodorkovskiy and Lebedev v. Russia (No. 2), app. nos. 51111/07 and 42757/07, 14.11.2020

20. Domenchini v Italy, 101/1995/607/695, 15.11.1996

21. Dragin v. Croatia, app. no. 75068/12, 24.6.2014

22. Margaretić v. Croatia, app. no. 16115/13, 5.62014

23. Perica Oreb v. Croatia, app. no. 20824/09, 31.10.2013

24. Peša v. Croatia, app. no. 40523/08, 8.4.2010

25. Dervishi v Croatia, app. no. 67341/10, 25.11.2012

26. Trifković v. Croatia, app. no. 36653/09, 6.11.2012

27. Oravec v. Croatia, no. 51249/11, 11.7.2017

28. Hadi v. Croatia, app. no. 42998/08, 1.7.2010

29. Bernobić v. Croatia, app. no. 57180/09, 21.6.2011

30. Krnjak v. Croatia, app. no. 11228/10, , 28.6.2011

31. Šebalj v. Croatia, app. no. 4429/09, 28.62011

32. Getoš-Magdić v. Croatia, app. no. 56305/08, 2.12.2010

33. Longin v. Croatia, app. no.49268/10, 6.11.2020,

34. Muršić v Croatia, app. no. 7334/13, 201.0.2016

35. Ulemek v Croatia, app. no. 21613/16, 31.10.2019 


\section{LIST OF NATIONAL REGULATIONS, ACTS AND COURT DECISIONS}

1. Constitution of Republic of Croatia, Official Gazette 56/90, 135/97, 113/00, 28/01, 76/10, $5 / 14$

2. Criminal Procedure Act, Official Gazette 152/08, 76/09, 80/11, 121/11, 91/12, 143/12, 56/13, 145/13, 152/14, 70/17, 126/19, 126/19

3. Act on Amendments to the CPA, Official Gazette 145/2013

4. Ordinance on house rules in prisons for the execution of pre-trial detention, Official Gazette $8 / 10$

5. Constitutional Court of Republic of Croatia, U-III-4182/2008, 23.4.2008

6. Constitutional Court of Republic of Croatia, U-IIIBi-890/2012, 4.5.2016

7. Constitutional Court of Republic of Croatia, U-IIIBi-2475/2016 Zagreb, 5.10.2016

8. Constitutional Court of Republic of Croatia, U-X-5464/2012, 12.6.2014

\section{WEB REFERENCES}

1. Aebi, M. F.; Tiago, M. M., Prisons and Prisoners in Europe 2019: Key Findings of the SPACE I report, [http://wp.unil.ch/space/files/2020/04/Key-Findings-2019200406.pdf], accessed 24. June 2020

2. Aebi, M. F.; Tiago, M.M., SPACE I - 2019 - Council of Europe Annual Penal Statistics: Prison populations. Strasbourg: Council of Europe, 2020), [http://wp.unil.ch/space/ files/2020/04/200405_FinalReport_SPACE_I_2019.pdf], accessed 24. June 2020

3. European Union Agency for Fundamental Rights, Criminal detention conditions in the European Union: rules and reality, Luxembourg, 2019, [https://fra.europa.eu/en/publication/2019/criminal-detention-conditions-european-union-rules-and-reality], accessed 15 . July 2020

4. European Union Agency for Fundamental Rights, Criminal detention conditions in the European Union: rules and reality, Luxembourg, 2019, [https://fra.europa.eu/en/publication/2019/criminal-detention-conditions-european-union-rules-and-reality], accessed 15 . July 2020

5. Guide on Article 6 of the European Convention on Human Rights, Right to a fair trial (criminal limb), Council of Europe/European Court of Human Rights, 2020, [https:// www.echr.coe.int/Documents/Guide_Art_6_criminal_ENG.pdf], accessed 18. July 2020

6. Izvješće o stanju i radu kaznionica, zatvora i odgojnih zavoda za 2018. Godinu, Vlada Republike Hrvatske, Zagreb, 2020., [https://www.sabor.hr/sites/default/files/uploads/sabor/2020-01-03/162702/IZVJESCE_KAZNIONICE2018.pdf], accessed 15. July 2020

7. Statistički ljetopis Republike Hrvatske 2018., Državni zavod za statistiku Republike Hrvatske, Zagreb, 2018, [https://www.dzs.hr/], accessed 15. July 2020

8. Van Ballegooij, W., Procedural Rights and Detention Conditions, Cost of Non - Europe Report, European Parliamentary Research Service, Bruxelles, 2017, [https://www.europarl.europa. eu/RegData/etudes/STUD/2017/611008/EPRS_STU(2017)611008_EN.pdf], accessed 24. June 2020 